\title{
Antiobesity Pharmacotherapy for Patients with Type 2 Diabetes: Focus on Long-Term Management
}

\author{
Won Seon Jeon, Cheol-Young Park \\ Division of Endocrinology and Metabolism, Department of Internal Medicine, Kangbuk Samsung Hospital, Sungkyunkwan \\ University School of Medicine, Seoul, Korea
}

Type 2 diabetes and obesity have a complex relationship; obesity is linked to insulin resistance, the precursor to type 2 diabetes. The management of obesity is an important method to delay onset of diabetes and improve the glycemic durability of antidiabetic agents. However, insulin and some of the oral hypoglycemic agents used to treat diabetes cause significant weight gain, and it is difficult for patients with diabetes to reduce and maintain their weight by life-style changes alone. Thus, antiobesity medications or bariatric surgery may be a necessary adjunct for certain obese patients with diabetes. In 2012, the U.S. Food and Drug Administration (FDA) approved lorcaserin and phentermine/topiramate extended-release for the management of chronic weight, and approval for naltrexone/bupropion sustained-release as an adjunct to exercise and reduced caloric intake followed in 2014. Liraglutide is pending FDA approval for antiobesity drug. Here we review the efficacy of approved and new promising drugs for the management of obesity.

Keywords: Obesity; Drug therapy; Diabetes

\section{INTRODUCTION}

The proportion of individuals with obesity and type 2 diabetes has increased rapidly worldwide [1]. Several epidemiological studies have confirmed the close relationship between diabetes and obesity [2,3]; more than $80 \%$ of patients with type 2 diabetes are estimated to be overweight or obese [4]. As the prevalence of obesity increases, the risk of type 2 diabetes is likely to increase [5]. Between 1980 and 1990, the majority of Korean patients with diabetes were nonobese; however, as the prevalence of obesity has increased in Korea, the majority of patients with diabetes are now obese. According to the Diabetes Fact Sheet in Korea 2012, the prevalence of type 2 diabetes was $10.1 \%$ in 2010 , and $75 \%$ of diabetic patients were over-

Corresponding author: Cheol-Young Park

Division of Endocrinology and Metabolism, Department of Internal Medicine, Kangbuk Samsung Hospital, Sungkyunkwan University School of Medicine, 29 Saemunan-ro, Jongno-gu, Seoul 110-746, Korea

Tel: $+82-2-2001-1869$, Fax: $+82-2-2001-1588$,

E-mail: cydoctor68@gmail.com weight or obese (i.e., a mean body mass index [BMI] of 25.2 $\mathrm{kg} / \mathrm{m}^{2}$ ).

Type 2 diabetes and obesity have a complex relationship, and obesity is linked to insulin resistance, the precursor to type 2 diabetes [2,3]. Obese adults are at increased risk of several chronic diseases, including cardiovascular disease, stroke, cancer, and type 2 diabetes [6-8]. Furthermore, the risk of death is increased $20 \%$ to $40 \%$ in overweight adults and 2- to 3 -fold in obese compared with normal weight adults [9]. Thus, treatment of obesity is crucial for the prevention of several health problems and for delayed onset of diabetes.

The management of obese patients with diabetes must include significant and sustained weight loss [10]. Moreover, weight reduction may affect the incidence of diabetes. Accord-

Copyright $\odot 2014$ Korean Endocrine Society

This is an Open Access article distributed under the terms of the Creative Commons Attribution Non-Commercial License (http://creativecommons.org/ licenses/by-nc/3.0/) which permits unrestricted non-commercial use, distribution, and reproduction in any medium, provided the original work is properly cited. 
ing to the Diabetes Prevention Program study [11], every kilogram of weight loss is correlated with a $16 \%$ reduction in the development of type 2 diabetes. Moderate weight reduction in obese patients with type 2 diabetes is associated with a decrease in insulin resistance, improved glycemic parameters, and reductions in diabetic complications and several cardiovascular disease-related risk factors [12]. The Action for Health Diabetes (Look AHEAD) study found that an 8.6\% weight loss together with intensive lifestyle intervention was associated with significant improvements in cardiovascular risk factors in 5,145 overweight or obese participants with type 2 diabetes $[13,14]$.

It is difficult for patients with diabetes to reduce and maintain their weight with lifestyle changes alone. Several oral hypoglycemic agents used to treat diabetes, such as sulfonylureas, glinides, and thiazolidinediones, and insulin are associated with significant weight gain that may impair metabolic conditions [15]. Thus, alternative antiobesity medications or bariatric surgery may be a necessary adjunct for obese patients with diabetes. Several placebo-controlled studies have shown that various medications help promote weight loss in obese patients with type 2 diabetes.

The focus of our review is antiobesity medications for the long-term treatment of obese patients with type 2 diabetes.

\section{FDA-APPROVED MEDICATIONS FOR LONG-TERM TREATMENT OF OBESITY}

The US Food and Drug Administration (FDA) approved the following drugs for use in adults with a BMI $\geq 30$ (obese) or $\geq 27$ (overweight) who had at least one weight-related condition such as type 2 diabetes, hypertension, or dyslipidemia.

\section{Orlistat}

Orlistat is a gastrointestinal lipase inhibitor that reduces the absorption of dietary fat. The recommended dose is $120 \mathrm{mg}$ three times daily before meals. A lower dose $(60 \mathrm{mg})$ is available as an over-the-counter preparation in the United States. One- and 2-year studies evaluating orlistat treatment for obesity have shown significant improvements in glycemic control and in blood pressure and lipid profiles [16]. In a large 4-year prospective study of 3,305 participants with BMI of $\geq 30 \mathrm{~kg} / \mathrm{m}^{2}$ and normal or impaired glucose tolerance (the Xenical in the Prevention of Diabetes in Obese subjects study), the orlistattreated group exhibited significant mean weight loss $(5.8 \mathrm{~kg}$ vs. $3.0 \mathrm{~kg}$ in the placebo group; $P<0.001)$ and reduced pro- gression to type 2 diabetes (risk reduction of $37.3 \%$ in the orlistat group; $P=0.0032$ ) [17]. A Korean study in which patients were administered orlistat for 24 weeks reported a modest but significant mean weight loss of $-2.73 \mathrm{~kg}$ (mean weight change, $-3.50 \% \pm 0.38 \%$ ) and significant improvements in lipid profiles, fasting insulin, waist circumference, blood pressure, fasting plasma glucose $(-10.41 \pm 4.62 \mathrm{mg} / \mathrm{dL})$, and glycosylated hemoglobin (HbA1c, $-0.87 \%$ ) [18].

The most common adverse effects of orlistat include flatus with discharge and oily spotting or fecal urgency, and the drug interferes with the absorption of fat soluble vitamins, although not tremendously $[17,19]$. Thus, subjects receiving orlistat are instructed to take vitamin supplements.

\section{Lorcaserin}

Lorcaserin is a selective serotonin $2 \mathrm{C}$ (5-HT2C) receptor agonist that suppresses appetite via stimulation of melanocortin receptor 4. The drug has low affinity for the 5-HT2B receptor, which is associated with the development of valvular heart disease and the cause of the withdrawal of agents such as dexfenfluramine [20].

In 2012, the FDA approved lorcaserin $10 \mathrm{mg}$ twice daily based on the findings of the pivotal randomized, placebo-controlled trials: Behavioral Modification and Lorcaserin for Overweight and Obesity Management (BLOOM), Behavioral Modification and Lorcaserin Second Study for Obesity Management (BLOSSOM), and BLOOM-diabetes mellitus (BLOOMDM) [21-23]. The BLOOM and BLOSSOM trials investigated the effect of lorcaserin on overweight or obese nondiabetic patients and found a $\sim 3 \%$ placebo-corrected weight change in the group treated with lorcaserin ( $20 \mathrm{mg} /$ day) (BLOOM, $-3.6 \%$; BLOSSOM, $-2.9 \%$; both $P<0.05$ ). Moreover, a significantly higher proportion of patients in the lorcaserin group lost $\geq 5 \%$ of their baseline body weight compared with the placebo group (approximately $47 \%$ vs. $20 \%$, respectively in the BLOOM; $47 \%$ vs. $25 \%$, respectively in the BLOSSOM trials). Furthermore, improvements in fasting glucose and triglyceride levels and blood pressure were observed in the lorcaserin groups.

The BLOOM-DM study included 604 overweight and obese patients with type 2 diabetes who were treated with metformin and/or sulfonylurea and randomized to lorcaserin 10 or $20 \mathrm{mg} /$ day or placebo groups for 52 weeks [23]. Consistent with the results of the BLOOM and BLOSSOM trials, the lorcaserintreated groups achieved weight losses of $-3.4 \%(10 \mathrm{mg})$ and $-3.1 \%(20 \mathrm{mg})$. A significantly higher proportion of patients 
in the lorcaserin groups lost $\geq 5 \%$ of their initial body weight (10 mg, 44.7\%; $20 \mathrm{mg}, 37.5 \%$ ) compared with patients administered placebo (16.1\%). The reduction in mean HbA1c was significantly greater in the lorcaserin-treated groups than in the placebo group (10 mg, $-1.0 \%$ change from baseline; 20 $\mathrm{mg},-0.9 \%$ change; and placebo, $-0.4 \%$ change; $P<0.001)$. A significantly higher proportion of patients in the lorcaserin groups achieved $\mathrm{HbA} 1 \mathrm{c} \leq 7 \%$ compared with patients treated with placebo (10 mg, 52.2\%; $20 \mathrm{mg}, 50.4 \%$; and placebo, $26.3 \%$ ). However, symptomatic hypoglycemia was more frequent in the lorcaserin groups (10 mg, 10.5\%; $20 \mathrm{mg}, 7.4 \%$ ) than in the placebo group (6.3\%).

The adverse events associated with lorcaserin include headache, dizziness, fatigue, nausea, dry-mouth, and constipation. No statistically significant difference in the occurrence of FDA-defined valvular disease was found between the lorcaserin and placebo groups. However, the postmarketing trials were required to evaluate the long-term cardiovascular effects of lorcaserin.

\section{Phentermine/topiramate extended-release}

Phentermine/Topiramate (PT) extended-release (ER) is a combination of the FDA-approved medications phentermine and topiramate in an ER formulation. Phentermine is indicated for short-term weight loss in overweight or obese adults who exercise and eat a reduced calorie diet. Topiramate is indicated for the treatment of certain types of seizures in people who have epilepsy and to prevent migraine headaches. The weight loss effect of phentermine is mediated by catecholamine release in the hypothalamus. The exact mechanism underlying the weight loss action of topiramate is not known; however, it may be associated with a combination of features such as an effect on sodium channels, enhancement of GABA-activated chloride channels, and inhibition of carbonic anhydrase isoenzymes [24]. The recommended daily dose of PT is $7.5 \mathrm{mg}$ phentermine/46 mg topiramate ER. PT is available at a higher dose (15 mg phentermine/92 mg topiramate ER) for select patients. Discontinuation or an increase in dosage is recommended for patients who have not lost 3\% of their baseline weight. Treatment should be discontinued if a weight loss $>5 \%$ of baseline is not achieved with $15 / 92 \mathrm{mg}$ per day.

FDA approval of PT was based on three phase III clinical trials performed to evaluate the efficacy of the drug (EQUIP, CONQUER, SEQUEL) [25-27]. In the EQUIP trial, 1,276 obese adults without diabetes were assigned randomly to a low- (3.75/23 mg/day) or high- (15/92 mg/day) dose PT or pla- cebo group for 56 weeks. At the conclusion of the study, the patients in the low- and high-dose PT and placebo groups lost $5.1 \%, 10.9 \%$, and $1.6 \%$ of their baseline body weight, respectively $(P<0.0001)$. Moreover, the results revealed improvements in waist circumference, triglyceride levels, and blood pressure.

The CONQUER trial included 2,487 overweight and obese patients with two or more weight-related comorbidities such as hypertension, prediabetes, type 2 diabetes, dyslipidemia, and abdominal adiposity. The participants were assigned to PT (7.5/46 or $15 / 92 \mathrm{mg}$ ) or placebo groups for 56 weeks. At the conclusion of the trial, the subjects in the $7.5 / 46 \mathrm{mg}$ group achieved a $-8.1 \mathrm{~kg}$ change in body weight (mean change $-7.8 \%$ ), those in the $15 / 92 \mathrm{mg}$ group a $-10.2 \mathrm{~kg}$ change (mean change $-9.8 \%$ ), and those in the placebo group a $-1.4 \mathrm{~kg}$ change (mean change $-1.2 \%$ ). A higher percentage of subjects in the PT groups achieved a $\geq 5 \%$ weight loss after 1 year compared with those receiving placebo $(62 \%, 70 \%$, and $21 \%$ in the $7.5 / 46$, $15 / 92 \mathrm{mg}$, and placebo groups, respectively; $P<0.001$ for both groups vs. placebo). Moreover, weight loss was maintained for a second year in the SEQUEL trial, a 52-week extension of the CONQUER trial. The CONQUER trial revealed an overall significant improvement in $\mathrm{HbA} 1 \mathrm{c}$ (\% change from baseline: $0 \%$, $-0.1 \%$, and $0.1 \%$ in the $7.5 / 46,15 / 92 \mathrm{mg}$, and placebo groups, respectively; $P<0.0001$ for both groups vs. placebo) and in fasting glucose levels ( $\%$ change from baseline: $-0.01 \%$, $-0.07 \%$, and $0.13 \%$ in the $7.5 / 46,15 / 92 \mathrm{mg}$, and placebo groups, respectively; $P=0.0047$ for $7.5 / 46 \mathrm{mg}$ vs. placebo and $P<0.0001$ for $15 / 92 \mathrm{mg}$ vs. placebo) at week 56. The progression to type 2 diabetes among participants without diabetes was lower in the PT-treated patients $(2.8 \%$ in the $7.5 / 46 \mathrm{mg}$ and $1.7 \%$ in the $15 / 92 \mathrm{mg}$ ) compared with those receiving the placebo $(3.6 \%)$. The relative risk of type 2 diabetes versus placebo was 0.78 (95\% confidence interval [CI], 0.40 to 1.50$)$ for the $7.5 / 46 \mathrm{mg}$ and 0.47 (95\% CI, 0.25 to 0.88 ) for the $15 / 92 \mathrm{mg}$ doses of PT.

An improvement in glycemic control was observed in the SEQUEL trial. At the conclusion of the trial (108 weeks), fasting glucose levels were significantly reduced from baseline in the $15 / 92 \mathrm{mg}$ dose group (the least-squared change in fasting glucose was 0.1 in the $7.5 / 46 \mathrm{mg},-1.2$ in the $15 / 92 \mathrm{mg}$, and 3.7 in the placebo groups; $P=0.0048$ for $15 / 92 \mathrm{mg}$ vs. placebo).

In the participants without type 2 diabetes at baseline, the progression of type 2 diabetes decreased during the 1-year extension. The annualized incidence rates for progression to type 2 diabetes were $0.9 \%, 1.7 \%$, and $3.7 \%$ in the $7.5 / 46,15 / 92$ 
$\mathrm{mg}$, and placebo groups, respectively, among the study participants without diabetes at baseline. These results revealed a $54 \%$ reduction in the progression to type 2 diabetes in the low$(7.5 / 46 \mathrm{mg})$ and a $76 \%$ reduction in the high-dose $(15 / 92 \mathrm{mg})$ groups compared with the placebo group [28]. Among participants with type 2 diabetes at baseline, HbAlc did not change markedly from baseline in the placebo group $(0 \%)$, whereas treatment with $7.5 / 46$ and $15 / 92 \mathrm{mg}$ PT led to $0.4 \%$ and $0.2 \%$ reductions in $\mathrm{HbAlc}$, respectively. However, the results of the SEQUEL trial should be interpreted with caution because, as an extension of the CONQUER trial, it may be subject to selection bias.

Common drug-related side effects include paresthesias, nausea, dizziness, constipation, and dry mouth. The reported neuropsychiatric adverse events include depression, anxiety, insomnia, and disturbances in attention. PT is contraindicated in pregnancy because of concerns about the teratogenicity of topiramate. Furthermore, PT may increase heart rate by two beats per minute; however, the FDA judged that the potential risk posed by an elevated heartbeat was outweighed by improvements in cardiovascular risk factors such as blood pressure [29].

\section{Naltrexone/bupropion sustained-release}

In September 2014, the FDA approved Naltrexone/bupropion (NB) sustained-release (SR) tablets as a treatment option for chronic weight management. Naltrexone was approved previously to treat alcohol and opioid dependence, and bupropion was approved for the treatment of depression or as an aid for smoking cessation. Naltrexone is an opioid receptor antagonist, and bupropion acts on adrenergic and dopaminergic receptors in the hypothalamus. Bupropion reduces energy intake and increases expenditure through neuronal effects. The combining of bupropion and naltrexone was based on the theory that naltrexone may block the compensatory mechanisms associated with bupropion that prevent sustained weight loss.

The efficacy of NB was evaluated by the Contrave Obesity Research (COR) program consisting of the COR-I, COR-II, COR trial with intensive behavior modification (CORBMOD), and COR-Diabetes trials (Table 1) [30-33]. The CORI, COR-II, and COR-BMOD trials evaluated overweight/obese patients without diabetes. Following treatment for 1 year, the group receiving naltrexone $32 \mathrm{mg} /$ bupropion $360 \mathrm{mg}$ lost 4 to $5 \mathrm{~kg}$ (approximately $-4 \%$ weight loss from baseline body weight) more than the placebo group, and $48 \%$ to $66 \%$ of the patients in the NB group lost $\geq 5 \%$ of their baseline body weight.

The COR-Diabetes trial evaluated the safety and efficacy of NB in 505 overweight or obese patients with type 2 diabetes over a 56-week period [34]. Participants were assigned to the naltrexone $32 \mathrm{mg} \mathrm{SR} /$ bupropion $360 \mathrm{mg}$ SR or placebo group. Compared with the placebo group, the patients treated with NB lost significantly more weight ( $-5.0 \%$ vs. $-1.8 \% ; P<0.001)$, and a higher proportion lost $\geq 5 \%$ of their body weight ( $44.5 \%$ vs. $18.9 \% ; P<0.001)$. Furthermore, baseline HbA1c was significantly reduced in the patients receiving NB compared with the placebo group ( $-0.6 \%$ vs. $-0.1 \%$, respectively; $P<0.001$ ), and $44.1 \%$ of patients receiving NB achieved $<7 \% \mathrm{HbA} 1 \mathrm{c}$ compared with $26.3 \%$ in the placebo group $(P<0.001)$. The incidence of hypoglycemia did not differ between groups. The cardiovascular safety of naltrexone $32 \mathrm{mg} \mathrm{SR} /$ bupropion 360 mg SR is currently under investigation (Clinical trial reg No. NCT01601704, clinicaltrials.gov).

The most common adverse events include nausea, constipation or diarrhea, headache, vomiting, dizziness, insomnia, and dry mouth. The NB provides a boxed warning to alert users to the increased risk of suicidal thoughts and behaviors associated with bupropion. The NB has a dose-related risk of seizures and may elevate blood pressure and heart rate.

\section{Liraglutide}

Liraglutide is a human glucagon-like peptide 1 analog that may be administered once a day because of its prolonged half-life of 13 hours [35]. Liraglutide was developed to improve glycemic control in patients with type 2 diabetes. The efficacy of the drug was well established in the Liraglutide Effect and Action in Diabetes (LEAD) studies, a series of phase III randomized, controlled trials $[36,37]$. The approved doses for the treatment of diabetes are 1.2 and $1.8 \mathrm{mg}$ in the United States and 0.6 and $0.9 \mathrm{mg}$ in Japan [38]. The LEAD-3 trial comprised 746 patients with type 2 diabetes assigned to liraglutide (1.2 or $1.8 \mathrm{mg}$ ) or glimepiride $(8 \mathrm{mg}$ ) treatment groups for 52 weeks [36]. The $\mathrm{HbAlc}$ reductions from baseline were $-0.84 \%$ and $-1.14 \%$ in the 1.2 and $1.8 \mathrm{mg}$ groups, respectively, and body weight was reduced by $-2.05 \mathrm{~kg}$ from baseline in the $1.2 \mathrm{mg}$ group and $-2.45 \mathrm{~kg}$ in the $1.8 \mathrm{mg}$ group, whereas a significant weight gain $(1.12 \mathrm{~kg})$ was observed in patients treated with glimepiride. A consistent reduction in body weight was observed across the LEAD trials.

Liraglutide is pending FDA approval for the treatment of obesity. The recommend dose is $3 \mathrm{mg}$ in contrast to 1.2 or 1.8 $\mathrm{mg}$ for diabetes. The Satiety and Clinical Adiposity-Liraglu- 


\begin{tabular}{|c|c|c|c|}
\hline Medication name/study & Inclusion criteria & Study design & $\begin{array}{c}\text { Weight loss efficacy } \\
\text { (mean body weight change) }\end{array}$ \\
\hline $\begin{array}{l}\text { Lorcaserin } \\
\text { BLOOM-DM (52 wk) }\end{array}$ & $\begin{array}{l}\text { BMI } 27-45 \mathrm{~kg} / \mathrm{m}^{2} \text { with type } 2 \text { diabetes; } \\
\text { treated with metformin, SU, or both; } \\
\mathrm{HbA} 1 \mathrm{c} 7 \%-10 \% \text { at screening visit }\end{array}$ & $\begin{array}{l}604 \text { Subjects were randomized to } \\
\text { placebo and } 10 \text { or } 20 \mathrm{mg} / \mathrm{day} \\
\text { lorcaserin }\end{array}$ & $\begin{array}{l}-1.5 \% \text { in the placebo group } \\
-5.0 \% \text { in the } 10 \mathrm{mg} / \text { day group } \\
(P<0.0001 \text { vs. placebo }) \\
-4.5 \% \text { in the } 20 \mathrm{mg} / \text { day group } \\
(P<0.0001 \text { vs. placebo })\end{array}$ \\
\hline $\begin{array}{l}\text { Phentermine/topiramate ER } \\
\text { CONQUER ( } 56 \mathrm{wk} \text { ) }\end{array}$ & $\begin{array}{l}\text { BMI } 27-45 \mathrm{~kg} / \mathrm{m}^{2} \text { with two or more } \\
\text { weight-related comorbidities }\end{array}$ & $\begin{array}{l}\text { 2,487 Subjects were randomized to } \\
\text { placebo and } 7.5 / 46 \text { and } 15 / 92 \mathrm{mg} \\
\text { phentermine/topiramate ER groups }\end{array}$ & $\begin{array}{l}-1.2 \% \text { in the placebo group } \\
-7.8 \% \text { in the } 7.5 / 46 \text { mg group } \\
(P<0.0001 \text { vs. placebo }) \\
-9.8 \% \text { in the } 15 / 92 \text { mg group } \\
(P<0.0001 \text { vs. placebo })\end{array}$ \\
\hline $\begin{array}{l}\text { Naltrexone/bupropion SR } \\
\text { COR-Diabetes ( } 56 \mathrm{wk} \text { ) }\end{array}$ & $\begin{array}{l}\text { BMI } 27-45 \mathrm{~kg} / \mathrm{m}^{2} \text { with type } 2 \\
\text { diabetes without insulin }\end{array}$ & $\begin{array}{l}505 \text { Subjects randomized to placebo } \\
\text { and 32/360 mg naltrexone/ } \\
\text { bupropion SR groups }\end{array}$ & $\begin{array}{l}-1.8 \% \text { in the placebo group } \\
-5.0 \% \text { in the } 32 / 360 \mathrm{mg} \text { group } \\
(P<0.001 \text { vs. placebo })\end{array}$ \\
\hline $\begin{array}{l}\text { Liraglutide } \\
\text { SCALE-Diabetes } \\
(56 \mathrm{wk})\end{array}$ & $\begin{array}{l}\text { BMI at least } 27 \mathrm{~kg} / \mathrm{m}^{2} \text { with type } 2 \\
\text { diabetes with or without oral } \\
\text { antidiabetic drugs }\end{array}$ & $\begin{array}{l}846 \text { Subjects were randomized to } \\
\text { placebo and } 1.8 \text { and } 3 \mathrm{mg} \text { liraglutide } \\
\text { groups }\end{array}$ & $\begin{array}{l}-2.0 \% \text { in the placebo group } \\
-5.9 \% \text { in the liraglutide } 3 \mathrm{mg} \text { group } \\
(P<0.001 \text { vs. placebo }) \\
-4.6 \% \text { in the liraglutide } 1.8 \mathrm{mg} \text { group } \\
(P<0.01 \text { vs. placebo })\end{array}$ \\
\hline
\end{tabular}

Modified from Henry et al. J Diabetes Complications 2013;27:508-18 [33].

BLOSSOM-DM, Behavioral Modification and Lorcaserin Second Study for Obesity Management diabetes mellitus; BMI, body mass index; SU, sulfonylurea; HbA1c, glycosylated hemoglobin; ER, extended-release; SR, sustained-release; COR, Contrave Obesity Research; SCALE, Satiety and Clinical Adiposity-Liraglutide Evidence in Nondiabetic and Diabetic Subjects.

tide Evidence in Nondiabetic and Diabetic Subjects (SCALE) trial consists of four clinical trials designed to demonstrate the safety and efficacy of liraglutide $3 \mathrm{mg}$ for weight management. The SCALE Obesity and Prediabetes phase IIIa trial involving 3,731 patients found that patients treated with liraglutide lost an average of $8 \%$ of their body weight in 56 weeks compared with $2.6 \%$ in the placebo group. Moreover, significantly more patients in the liraglutide group lost $\geq 5 \%$ of their baseline body weight compared with those taking the placebo (63.5\% vs. $26.6 \%$, respectively), and $32.8 \%$ of the liraglutide group lost $>10 \%$ of their baseline body weight $(10.1 \%$ in the placebo group).

The SCALE-Diabetes trial was a 56-week randomized, placebo-controlled trial designed to investigate the potential of liraglutide $3 \mathrm{mg}$ in obese or overweight patients with type 2 diabetes. In this trial, 846 overweight or obese patients with diabetes were assigned randomly to liraglutide $3 \mathrm{mg}$ or $1.8 \mathrm{mg}$ or placebo groups. After 56 weeks, the 3 and $1.8 \mathrm{mg}$ liraglutide groups achieved weight loses of $6 \%$ and $5 \%$, respectively, compared with $2 \%$ in the placebo group. Furthermore, $50 \%$ of the patients in the $3 \mathrm{mg}$ group and $35 \%$ of those in the $1.8 \mathrm{mg}$ group achieved $\geq 5 \%$ weight loss compared with $13 \%$ in the placebo group, and approximately $69 \%$ of the patients treated with liraglutide $3 \mathrm{mg}$ achieved the $\mathrm{HbAlc}$ target of $<7 \%$ (Clinical trial reg No. NCT01272232, clinicaltrials.gov).

Concerned by the lack of long-term data for liraglutide in the treatment of obesity and a variety of safety issues, such as gallbladder disease, pancreatitis, breast and thyroid cancers, and increased heart rate, the FDA advisory panel recommended that these issues be addressed in postmarketing studies. However, the panel agreed that the ongoing cardiovascular outcomes trial of the Liraglutide Effect and Action in Diabetes: Evaluation of Cardiovascular Outcome Results study would be sufficient to characterize the cardiovascular risk of the liraglutide.

\section{CONCLUSIONS}

It is clear that weight management is essential for obese patients with diabetes. Exercise and monitoring food intake are 


\begin{tabular}{|c|c|c|c|}
\hline Generic name (brand) & Recommended dose & Action mechanism & Adverse effects and concerns \\
\hline Orlistat (Xenical, Roche) & $120 \mathrm{mg} 3$ times daily & Lipase inhibitor & $\begin{array}{l}\text { Flatus with discharge, fecal urgency, } \\
\text { fatty oily stool, fecal incontinence }\end{array}$ \\
\hline Lorcaserin (Belviq, Arena) & $10 \mathrm{mg}$ twice daily & $\begin{array}{l}\text { Selective serotonergic 5-HT2C } \\
\text { receptor agonist }\end{array}$ & $\begin{array}{l}\text { Headache, dizziness, nausea, dry } \\
\text { mouth, constipation }\end{array}$ \\
\hline $\begin{array}{l}\text { Phentermine/topiramate ER } \\
\text { (Qsymia, Vivus) }\end{array}$ & $\begin{array}{l}3.75 / 23 \mathrm{mg} \text { for } 2 \text { weeks, } \\
\text { increased to } 7.5 / 46 \mathrm{mg} \\
\text { maximum dose of } 15 / 92 \mathrm{mg}\end{array}$ & $\begin{array}{l}\text { Phentermine: centrally acting } \\
\text { sympathomimetic amine } \\
\text { Topiramate: unknown, but relation to } \\
\text { GABA activated ion channel and } \\
\text { inhibition of carbonic anhydrase }\end{array}$ & $\begin{array}{l}\text { Paresthesia, dry-mouth, constipation, } \\
\text { insomnia, elevation in heart rate, } \\
\text { concern for teratogenicity }\end{array}$ \\
\hline $\begin{array}{l}\text { Naltrexone/bupropion SR } \\
\text { (Contrave, Orexigen) }\end{array}$ & $\begin{array}{l}\text { 32/360 mg daily } \\
\text { (start with 8/90 mg for } 1 \text { week, } \\
\text { increase every week, } \\
\text { recommended } \\
\text { dose reached on week 4) }\end{array}$ & $\begin{array}{l}\text { Naltrexone: complement to bupropion for } \\
\text { blocking compensating mechanism } \\
\text { Bupropion: noradrenaline and dopamine } \\
\text { reuptake inhibitor }\end{array}$ & $\begin{array}{l}\text { Nausea, constipation, headache, } \\
\text { vomiting, dizziness, insomnia, } \\
\text { dry-mouth } \\
\text { Concerns of seizure, suicidal thoughts, } \\
\text { and elevated blood pressure and heart } \\
\text { rate }\end{array}$ \\
\hline $\begin{array}{l}\text { Liraglutide } \\
\text { (Saxenda, Novo Nordisk) }\end{array}$ & $3 \mathrm{mg}$ daily & GLP-1 receptor agonist & $\begin{array}{l}\text { Nausea, constipation, diarrhea, and } \\
\text { vomiting, concern for thyroid cancer/ } \\
\text { pancreatitis }\end{array}$ \\
\hline
\end{tabular}

5-HT2C, serotonin 2C; ER, extended-release; GABA, gamma-aminobutyric acid; SR, sustained-release; GLP-1, glucagon-like peptide 1.

important components of a weight loss regime; however, it is difficult for patients to reduce and maintain their weight by lifestyle changes alone; thus, safe and effective long-term antiobesity drugs may be a necessary adjunct to lifestyle modification. The five drugs currently approved or pending FDA approval for long-term treatment of obesity are orlistat, lorcaserin, PT, NB, and liraglutide (Table 2). These medications have been shown to reduce weight by $5 \%$ to $10 \%$, improve glycemic profiles significantly, and reduce cardiovascular risk in patients with diabetes. However, possible adverse events should be monitored, and these medications must be considered as part of a comprehensive management regime for obese patients with diabetes. Further study of neuropeptide-Y, $\beta 3$ adrenergic receptors, oxyntomodulin, and amylin analogues are warranted for the development of future antiobesity medications.

\section{CONFLICTS OF INTEREST}

No potential conflict of interest relevant to this article was reported.

\section{REFERENCES}

1. Shaw JE, Sicree RA, Zimmet PZ. Global estimates of the prevalence of diabetes for 2010 and 2030. Diabetes Res Clin Pract 2010;87:4-14.

2. Yang W, Lu J, Weng J, Jia W, Ji L, Xiao J, Shan Z, Liu J, Tian H, Ji Q, Zhu D, Ge J, Lin L, Chen L, Guo X, Zhao Z, Li Q, Zhou Z, Shan G, He J; China National Diabetes and Metabolic Disorders Study Group. Prevalence of diabetes among men and women in China. N Engl J Med 2010;362: 1090-101.

3. Eckel RH, Kahn SE, Ferrannini E, Goldfine AB, Nathan DM, Schwartz MW, Smith RJ, Smith SR. Obesity and type 2 diabetes: what can be unified and what needs to be individualized? J Clin Endocrinol Metab 2011;96:1654-63.

4. Scheen AJ, Ernest P. New antiobesity agents in type 2 diabetes: overview of clinical trials with sibutramine and orlistat. Diabetes Metab 2002;28(6 Pt 1):437-45.

5. Chan JM, Rimm EB, Colditz GA, Stampfer MJ, Willett WC. Obesity, fat distribution, and weight gain as risk factors for clinical diabetes in men. Diabetes Care 1994;17: 961-9. 
6. Mokdad AH, Ford ES, Bowman BA, Dietz WH, Vinicor F, Bales VS, Marks JS. Prevalence of obesity, diabetes, and obesity-related health risk factors, 2001. JAMA 2003;289: 76-9.

7. Berger NA. Obesity and cancer pathogenesis. Ann N Y Acad Sci 2014;1311:57-76.

8. Field AE, Coakley EH, Must A, Spadano JL, Laird N, Dietz WH, Rimm E, Colditz GA. Impact of overweight on the risk of developing common chronic diseases during a 10-year period. Arch Intern Med 2001;161:1581-6.

9. Adams KF, Schatzkin A, Harris TB, Kipnis V, Mouw T, Ballard-Barbash R, Hollenbeck A, Leitzmann MF. Overweight, obesity, and mortality in a large prospective cohort of persons 50 to 71 years old. N Engl J Med 2006;355: 763-78.

10. Expert Panel on the Identification, Evaluation, and Treatment of Overweight in Adults. Clinical guidelines on the identification, evaluation, and treatment of overweight and obesity in adults: executive summary. Am J Clin Nutr 1998; 68:899-917.

11. Hamman RF, Wing RR, Edelstein SL, Lachin JM, Bray GA, Delahanty L, Hoskin M, Kriska AM, Mayer-Davis EJ, Pi-Sunyer X, Regensteiner J, Venditti B, Wylie-Rosett J. Effect of weight loss with lifestyle intervention on risk of diabetes. Diabetes Care 2006;29:2102-7.

12. American Diabetes Association. Standards of medical care in diabetes: 2012. Diabetes Care 2012;35 Suppl 1:S11-63.

13. Look AHEAD Research Group, Wing RR. Long-term effects of a lifestyle intervention on weight and cardiovascular risk factors in individuals with type 2 diabetes mellitus: four-year results of the Look AHEAD trial. Arch Intern Med 2010;170:1566-75.

14. Wadden TA, Neiberg RH, Wing RR, Clark JM, Delahanty LM, Hill JO, Krakoff J, Otto A, Ryan DH, Vitolins MZ; Look AHEAD Research Group. Four-year weight losses in the Look AHEAD study: factors associated with long-term success. Obesity (Silver Spring) 2011;19:1987-98.

15. Bray GA, Ryan DH. Medical therapy for the patient with obesity. Circulation 2012;125:1695-703.

16. Rossner S, Sjostrom L, Noack R, Meinders AE, Noseda G. Weight loss, weight maintenance, and improved cardiovascular risk factors after 2 years treatment with orlistat for obesity. European Orlistat Obesity Study Group. Obes Res 2000;8:49-61.

17. Torgerson JS, Hauptman J, Boldrin MN, Sjostrom L. XENical in the prevention of diabetes in obese subjects (XEN-
DOS) study: a randomized study of orlistat as an adjunct to lifestyle changes for the prevention of type 2 diabetes in obese patients. Diabetes Care 2004;27:155-61.

18. Chon S, Park C, Koh G, Oh S, Woo JT, Kim SW, Kim JW, Kim YS, Son HY, Cha BY, Yoon KH, Kwon HS, Cha BS, Lee HC. The effect of orlistat in obese patients with type 2 diabetes: benefit on abdominal obesity and glycemic control. J Korean Soc Study Obes 2004;13:281-92.

19. Davidson MH, Hauptman J, DiGirolamo M, Foreyt JP, Halsted CH, Heber D, Heimburger DC, Lucas CP, Robbins DC, Chung J, Heymsfield SB. Weight control and risk factor reduction in obese subjects treated for 2 years with orlistat: a randomized controlled trial. JAMA 1999;281:23542.

20. Zhou L, Sutton GM, Rochford JJ, Semple RK, Lam DD, Oksanen LJ, Thornton-Jones ZD, Clifton PG, Yueh CY, Evans ML, McCrimmon RJ, Elmquist JK, Butler AA, Heisler LK. Serotonin $2 \mathrm{C}$ receptor agonists improve type 2 diabetes via melanocortin-4 receptor signaling pathways. Cell Metab 2007;6:398-405.

21. Smith SR, Weissman NJ, Anderson CM, Sanchez M, Chuang E, Stubbe S, Bays H, Shanahan WR; Behavioral Modification and Lorcaserin for Overweight and Obesity Management (BLOOM) Study Group. Multicenter, placebo-controlled trial of lorcaserin for weight management. $\mathrm{N}$ Engl J Med 2010;363:245-56.

22. Fidler MC, Sanchez M, Raether B, Weissman NJ, Smith SR, Shanahan WR, Anderson CM; BLOSSOM Clinical Trial Group. A one-year randomized trial of lorcaserin for weight loss in obese and overweight adults: the BLOSSOM trial. J Clin Endocrinol Metab 2011;96:3067-77.

23. O’Neil PM, Smith SR, Weissman NJ, Fidler MC, Sanchez M, Zhang J, Raether B, Anderson CM, Shanahan WR. Randomized placebo-controlled clinical trial of lorcaserin for weight loss in type 2 diabetes mellitus: the BLOOMDM study. Obesity (Silver Spring) 2012;20:1426-36.

24. Wyatt HR. Update on treatment strategies for obesity. J Clin Endocrinol Metab 2013;98:1299-306.

25. Allison DB, Gadde KM, Garvey WT, Peterson CA, Schwiers ML, Najarian T, Tam PY, Troupin B, Day WW. Controlled-release phentermine/topiramate in severely obese adults: a randomized controlled trial (EQUIP). Obesity (Silver Spring) 2012;20:330-42.

26. Gadde KM, Allison DB, Ryan DH, Peterson CA, Troupin B, Schwiers ML, Day WW. Effects of low-dose, controlled-release, phentermine plus topiramate combination 
on weight and associated comorbidities in overweight and obese adults (CONQUER): a randomised, placebo-controlled, phase 3 trial. Lancet 2011;377:1341-52.

27. Garvey WT, Ryan DH, Look M, Gadde KM, Allison DB, Peterson CA, Schwiers M, Day WW, Bowden CH. Twoyear sustained weight loss and metabolic benefits with controlled-release phentermine/topiramate in obese and overweight adults (SEQUEL): a randomized, placebo-controlled, phase 3 extension study. Am J Clin Nutr 2012;95: 297-308.

28. Davidson MH, Tonstad S, Oparil S, Schwiers M, Day WW, Bowden CH. Changes in cardiovascular risk associated with phentermine and topiramate extended-release in participants with comorbidities and a body mass index $\geq$ $27 \mathrm{~kg} / \mathrm{m}(2)$. Am J Cardiol 2013;111:1131-8.

29. Colman E, Golden J, Roberts M, Egan A, Weaver J, Rosebraugh C. The FDA's assessment of two drugs for chronic weight management. N Engl J Med 2012;367:1577-9.

30. Greenway FL, Fujioka K, Plodkowski RA, Mudaliar S, Guttadauria M, Erickson J, Kim DD, Dunayevich E; CORI Study Group. Effect of naltrexone plus bupropion on weight loss in overweight and obese adults (COR-I): a multicentre, randomised, double-blind, placebo-controlled, phase 3 trial. Lancet 2010;376:595-605.

31. Apovian CM, Aronne L, Rubino D, Still C, Wyatt H, Burns C, Kim D, Dunayevich E; COR-II Study Group. A randomized, phase 3 trial of naltrexone SR/bupropion SR on weight and obesity-related risk factors (COR-II). Obesity (Silver Spring) 2013;21:935-43.

32. Wadden TA, Foreyt JP, Foster GD, Hill JO, Klein S, O’Neil PM, Perri MG, Pi-Sunyer FX, Rock CL, Erickson JS, Maier HN, Kim DD, Dunayevich E. Weight loss with naltrexone SR/bupropion SR combination therapy as an adjunct to behavior modification: the COR-BMOD trial. Obesity
(Silver Spring) 2011;19:110-20.

33. Henry RR, Chilton R, Garvey WT. New options for the treatment of obesity and type 2 diabetes mellitus (narrative review). J Diabetes Complications 2013;27:508-18.

34. Hollander P, Gupta AK, Plodkowski R, Greenway F, Bays H, Burns C, Klassen P, Fujioka K; COR-Diabetes Study Group. Effects of naltrexone sustained-release/bupropion sustained-release combination therapy on body weight and glycemic parameters in overweight and obese patients with type 2 diabetes. Diabetes Care 2013;36:4022-9.

35. Degn KB, Juhl CB, Sturis J, Jakobsen G, Brock B, Chandramouli V, Rungby J, Landau BR, Schmitz O. One week's treatment with the long-acting glucagon-like peptide 1 derivative liraglutide (NN2211) markedly improves 24-h glycemia and alpha- and beta-cell function and reduces endogenous glucose release in patients with type 2 diabetes. Diabetes 2004;53:1187-94.

36. Garber A, Henry R, Ratner R, Garcia-Hernandez PA, Rodriguez-Pattzi H, Olvera-Alvarez I, Hale PM, Zdravkovic M, Bode B; LEAD-3 (Mono) Study Group. Liraglutide versus glimepiride monotherapy for type 2 diabetes (LEAD-3 Mono): a randomised, 52-week, phase III, double-blind, parallel-treatment trial. Lancet 2009;373:473-81.

37. Marre M, Shaw J, Brandle M, Bebakar WM, Kamaruddin NA, Strand J, Zdravkovic M, Le Thi TD, Colagiuri S; LEAD$1 \mathrm{SU}$ study group. Liraglutide, a once-daily human GLP-1 analogue, added to a sulphonylurea over 26 weeks produces greater improvements in glycaemic and weight control compared with adding rosiglitazone or placebo in subjects with type 2 diabetes (LEAD-1 SU). Diabet Med 2009;26: 268-78.

38. Bode B. An overview of the pharmacokinetics, efficacy and safety of liraglutide. Diabetes Res Clin Pract 2012;97:27-42. 